\title{
Wpływ rodzaju fazy zdyspergowanej na właściwości tribologiczne smarów plastycznych wytworzonych na oleju Inianym
}

\begin{abstract}
W artykule przedstawiono wyniki badań wpływu fazy zdyspergowanej na właściwości tribologiczne wybranych kompozycji smarowych. Do wytworzenia smarów plastycznych użyto oleju lnianego, który następnie zagęszczono stearynianem litu, stearynianem glinu, stearynianem wapnia, modyfikowaną krzemionką typu Aerosil ${ }^{\circledR}$ oraz montmorylonitem. Wykonano badania właściwości tribologicznych objęte normą dla smarów plastycznych za pomocą testera tribologicznego T-02, a uzyskane wyniki porównano ze sobą i oceniono wpływ rodzaju zagęszczacza na wartość badanych parametrów. Do oceny właściwości tribologicznych wykorzystano wyniki badań granicznego obciążenia zużycia, obciążenia zespawania, obciążenia zacierającego, granicznego obciążenia zatarcia oraz granicznego nacisku zatarcia. Na podstawie wyników badań tribologicznych wybranych kompozycji smarowych stwierdzono, że najkorzystniejszymi właściwościami przeciwzużyciowymi charakteryzują się kompozycje, w których jako fazę zdyspergowaną zastosowano stearynian wapnia oraz montmorylonit, natomiast najskuteczniejszą ochronę przeciwzatarciową pełnią kompozycje, w których fazą zdyspergowaną był montmorylonit oraz modyfikowana krzemionka amorficzna Aerosil ${ }^{\mathbb{B}}$.
\end{abstract}

Słowa kluczowe: smar plastyczny, olej bazowy, zagęszczacz, właściwości przeciwzużyciowe, właściwości przeciwzatarciowe, aparat czterokulowy.

\section{The influence of dispersed type phase on tribological properties of lubricating greases to form on the linseed oil}

The paper presents the results of investigations concerning the influence of dispersed phase on tribological properties of selected lubricating compositions. For the production lubricating greases linseed oil was used, which was then thickened with lithium stearate, aluminum stearate, calcium stearate, modified amorphous silica Aerosil ${ }^{\circledR}$ and montmorillonite. The investigations of tribological properties were carried out for lubricating greases using the tribology tester T-02 and the obtained results were compared with each other and the influence of thickener type on the values of tested parameters was evaluated. For the estimation of tribological properties, results of investigations limiting load of wear $\left(G_{o z} / 40\right)$, welding load $\left(P_{z}\right)$, scuffing load $\left(P_{t}\right)$, limiting load of scuffing $\left(P_{o z}\right)$ and the limiting pressure of seizure $\left(P_{o z}\right)$ were used. Based on the obtained results of tribological investigations of selected lubricating compositions, it was concluded that the most favorable antiwear properties are compositions, wherein calcium stearate and montmorillonite were used as the dispersed phase, while the best antiscuffing protection have compositions, wherein as the dispersed phase was used montmorillonite and modified amorphous silica Aerosil ${ }^{\mathbb{B}}$.

Key words: lubricating grease, base oil, thickener, antiwear properties, antiscuffing properties, four-ball machine.

\section{Wprowadzenie}

W ostatnich latach coraz większego znaczenia nabiera ochrona środowiska naturalnego. Przepisy i akty prawne UE kładą duży nacisk na ograniczenie stosowania, a co za tym idzie wprowadzania do środowiska szkodliwych ekologicznie naftowych środków smarowych [5, 10, 45]. Poszukuje się więc takich komponentów, które charakteryzowałyby się wysoką biodegradowalnością oraz nietoksycznością. Wymagania takie spełniają składniki pochodzenia roślinnego, które coraz częściej są stosowane do wytworzenia ekologicznych środków smarowych [4, 16, 25, 43, 47]. Nietoksyczność i biode- 
gradowalność środków smarowych jest szczególnie pożądane w przypadku stosowania tych produktów w urządzeniach przemysłu spożywczego [28, 30].

Aplikacje w wymienionej gałęzi przemysłu wymagają wytworzenia środków smarowych o odpowiednio dobranych komponentach, w szczególności nietoksycznych olejowych, które zapewnią produktowi końcowemu charakter ekologiczny $[3,22,23,53]$.

Obecnie wzrasta zainteresowanie możliwością wykorzystania olejów roślinnych do produkcji środków smarowych głównie ze względu na ochronę środowiska. Obserwuje się wzrost tendencji do zastępowania słabo biodegradowalnych produktów naftowych, zanieczyszczających środowisko naturalne nietoksycznymi produktami roślinnymi. Oleje roślinne mają bardzo dobre właściwości lepkościowo-temperaturowe oraz smarne, które warunkują ich przydatność jako bazy olejowej smarów plastycznych. Do podstawowych wad tych produktów należy niska odporność na hydrolizę, a przede wszystkim mała odporność termiczna i oksydacyjna [6, 11, 12, 14, 15, 17, 18, 54].

Smary plastyczne są substancjami składającymi się z fazy dyspergującej, fazy zdyspergowanej oraz dodatków uszlachetniających. Fazę zdyspergowaną stanowią zwykle proste i kompleksowe mydła litowe, sodowe, glinowe i wapniowe, a także bentonit, poliuretany, krzemionka oraz parafiny, woski i polimery. Zawartość fazy zdyspergowanej w smarze wynosi zazwyczaj od kilku do kilkudziesięciu procent [19, 40, 50]. Od ilości i rodzaju fazy zdyspergowanej zależą właściwości eksploatacyjne kompozycji smarowej. Podczas wytwarzania smaru plastycznego dobiera się taką substancję, która nadawać będzie otrzymanemu produktowi odpowiednie właściwości tribologiczne, reologiczne, korozyjne czy mechaniczne [9]. W ostatnich latach coraz częściej jako fazę zdyspergowaną smarów plastycznych stosuje się substancje nieorganiczne, które charakteryzują się doskonałymi zdolnościami do przenoszenia obciążeń, wysoką temperaturą topnienia, poprawiają wydajność smarowania, zmniejszają zużycie i zwiększają odporność chemiczną oraz termiczną powstałego środka smarowego [7, 8, 39, 48]. Stosowanie mydeł kompleksowych jako zagęszczaczy smarów plastycznych powoduje zwiększenie temperatury kroplenia środków smarowych, poprawie ulega ich odporność mechaniczna oraz strukturalna i właściwości tribologiczne. Dlatego coraz częściej zagęszczacze kompleksowe oraz nieorganiczne wypierają z rynku zagęszczacze konwencjonalne, takie jak np. mydła proste [52].

Celem pracy było zbadanie wpływu rodzaju fazy zdyspergowanej na zmianę podstawowych parametrów tribologicznych dla kompozycji smarowych wytworzonych z udziałem roślinnej bazy olejowej i mających zastosowanie w przemyśle spożywczym, opracowanych w Instytucie Technologii Eksploatacji - Państwowym Instytucie Badawczym w Radomiu.

\section{Część doświadczalna}

\section{Charakterystyka obiektów badań}

Opracowano grupę modelowych kompozycji smarowych z zastosowaniem nietoksycznych składników stanowiących fazę dyspergującą i zdyspergowaną. Jako fazę dyspergującą zastosowano olej lniany. Olej bazowy zastosowany do wytworzenia smarów plastycznych był poddany procesowi rafinacji. Natomiast jako fazę zdyspergowaną zastosowano stearynian litu [13, 41, 42, 44], stearynian wapnia [1], stearynian glinu [41, 42, 46], modyfikowaną krzemionkę typu Aerosil ${ }^{\circledR}$ [26, 27, 29] oraz montmorylonit [27, 29, 31]. Wykorzystując wybrane składniki, wytworzono smary plastyczne mieszczące się w drugiej klasie konsystencji i mające zastosowanie w przemyśle spożywczym. Klasę konsystencji wytworzonych kompozycji smarowych zbadano zgodnie z wymaganiami normy PN-ISO 2137:2011, używając penetrometru laserowego wyprodukowanego przez ITeE - PIB [1, 2, 37, 38]. W tablicy 1 przedstawiono skład badanych smarów plastycznych. Przyjęto następujące oznaczenia kompozycji wytworzonych na bazie oleju lnianego i zagęszczonych odpowiednio: stearynianem litu (smar A), stearynianem glinu (smar B), stearynianem wapnia (smar C), modyfikowaną krzemionką Aerosil ${ }^{\circledR}$ (smar D) oraz montmorylonitem (smar E).

W kompozycjach smarowych zastosowanych w eksperymencie wprowadzono różną ilość fazy zdyspergowanej $(7 \div 12 \%(\mathrm{~m} / \mathrm{m}))$. Różna zawartość zagęszczaczy w badanych smarach wynikała $z$ tego, że założono, iż wytworzone smary plastyczne muszą się zmieścić w drugiej klasie konsystencji (wartość penetracji musi wynosić $265 \div 295 \mathrm{~mm} / 10$ ). We wczesnej fazie eksperymentu podjęto badania nad ilością zagęszczacza,
Tablica 1. Skład chemiczny badanych smarów plastycznych

\begin{tabular}{|c|c|c|c|}
\hline $\begin{array}{c}\text { Oznakowanie } \\
\text { badanego smaru }\end{array}$ & Faza dyspergująca & Faza zdyspergowana & $\begin{array}{c}\text { Penetracja } \\
{[\mathrm{mm} / 10]}\end{array}$ \\
\hline A & olej lniany (92\%) & stearynian litu (8\%) & 279,00 \\
\hline B & olej lniany (93\%) & stearynian glinu (7\%) & 267,75 \\
\hline C & olej lniany (91\%) & stearynian wapnia (9\%) & 271,50 \\
\hline D & olej lniany (90\%) & krzemionka Aerosil ${ }^{\circledR}(10 \%)$ & 294,00 \\
\hline E & olej lniany (88\%) & montmorylonit $(12 \%)$ & 286,50 \\
\hline
\end{tabular}


jaką należy wprowadzić do bazy olejowej, aby uzyskać kompozycje smarowe mieszczące się $\mathrm{w}$ drugiej klasie konsystencji. Przeprowadzono testy z kompozycjami zawierającymi od
5 do $15 \%$ fazy zdyspergowanej. Tak przygotowane kompozycje smarowe poddano następnie badaniom właściwości tribologicznych.

\section{Badania właściwości tribologicznych}

\section{Aparatura}

Do wyznaczenia właściwości tribologicznych badanych kompozycji smarowych wykorzystano aparat czterokulowy T-02 $[26,27,29,31,51]$. Dla wyznaczenia wymiarów śladu zużycia powierzchni kulek testowych zastosowano mikroskop optyczny Nikon MM-40 [28, 29, 30, 31]. Uzyskane wyniki posłużyły do określenia wartości $G_{o z / 40}$ oraz $p_{o z}$, czyli oceny właściwości przeciwzużyciowych i przeciwzatarciowych smarów plastycznych poddanych badaniom tribologicznym [32-36].

\section{Sposób prowadzenia badań}

Właściwości tribologiczne badanych kompozycji smarowych zostały określone poprzez pomiar granicznego obciążenia zużycia $\left(G_{o z / 40}\right)$, obciążenia zespawania $\left(P_{z}\right)$, obciążenia zacierającego $\left(P_{t}\right)$, granicznego obciążenia zatarcia $\left(P_{o z}\right)$ oraz granicznego nacisku zatarcia $\left(p_{o z}\right)[27,29,31,33,34,35]$. Elementami testowymi były kulki o średnicy $12,7 \mathrm{~mm}$ wykonane ze stali łożyskowej ŁH 15, o chropowatości powierzchni $R a=0,32 \mu \mathrm{m}$ i twardości $60 \div 65$ HRC [50,51]. Pomiar granicznego obciążenia zużycia $\left(G_{o z / 40}\right)$ wykonano przy obciążeniu węzła tarcia siłą 392,4 N przez cały czas trwania testu - 3600 s oraz przy prędkości obrotowej kulki wynoszącej $500 \mathrm{obr} / \mathrm{min}$ zgodnie z warunkami testu przewidzianymi w WTWT-94/MPS-025 [27, 29, 31, 33, 34, 35, 56]. Pomiar obciążenia zespawania przeprowadzono zgodnie z normą PN-76/C-04147 [55]. Oznaczenie to polegało na przeprowadzeniu 10-sekundowych biegów zespołu czterech kulek w obecności środka smarowego pod coraz większym obciążeniem aż do zespawania kulek. Natomiast pomiar właściwości smarnych $\mathrm{w}$ warunkach zacierania (tj. pod ciągle wzrastającym obciążeniem w czasie biegu badawczego) prowadzono zgodnie z metodyką opracowaną przez ITeE - PIB. Badanie wykonano przy liniowo wzrastającym obciążeniu od 0 do $7200 \mathrm{~N}$ w czasie $18 \mathrm{~s}$ przy prędkości wrzeciona $500 \mathrm{obr} / \mathrm{min}$ i prędkości narastania obciążenia 409 N/s. Gdy następuje nagły wzrost momentu tarcia to poziom obciążenia węzła określany jest jako obciążenie zacierające $P_{t}[27,29,31,33]$. Pomiar prowadzono do momentu osiągnięcia granicznego momentu tarcia $10 \mathrm{Nm}$ lub maksymalnego obciążenia aparatu $7200 \mathrm{~N}$. Ten punkt określono jako graniczne obciążenie zatarcia $P_{o z}[27,33,51,56]$. Za wynik końcowy przyjmowano średnią arytmetyczną z co najmniej trzech oznaczeń nieróżniących się od siebie więcej niż $10 \%$. Do obróbki statystycznej wyników zastosowano test Q-Dixona przy poziomie ufności 95\%.
Graniczny nacisk zatarcia jest miarą właściwości przeciwzatarciowych środków smarowych w warunkach zacierania. Oznaczenie tego parametru polegało na wyliczeniu jego wartości zgodnie ze wzorem:

$$
p_{o z}=0,52 \cdot P_{o z} / d_{o z}{ }^{2}
$$

gdzie: $P_{o z}$ - graniczne obciążenie zatarcia, a $d_{o z}$ - średnica skazy powstałej na kulkach stalowych użytych do badania $[29,30,51,55]$.

Niepewność wyznaczenia badanych wielkości (granicznego obciążenia zużycia $G_{o z / 40}$, obciążenia zespawania $P_{z}$, obciążenia zacierającego $P_{t}$, granicznego obciążenia zatarcia $P_{o z}$ oraz granicznego nacisku zatarcia $p_{o z}$ ) oszacowano na podstawie klasy dokładności zastosowanej aparatury pomiarowej. Przynależność poszczególnych wyników badanych wielkości, tj. $G_{o z / 40}, P_{z}, P_{t}, P_{o z}$ i $p_{o z}$, do zbioru danych weryfikowano za pomocą testu Q-Dixona przy $95 \%$ poziomie ufności.

\section{Omówienie wyników}

Poniżej przedstawiono wyniki badań tribologicznych (właściwości przeciwzatarciowych i przeciwzużyciowych) kompozycji smarowych wytworzonych na oleju lnianym i zagęszczonych odpowiednio stearynianem litu, stearynianem glinu, stearynianem wapnia, modyfikowaną krzemionką typu Aerosil ${ }^{\circledR}$ oraz montmorylonitem.

Dla wybranych kompozycji smarowych wyznaczono obciążenie zespawania $P_{z}$. Uzyskane wyniki przedstawiono na rysunku 1.

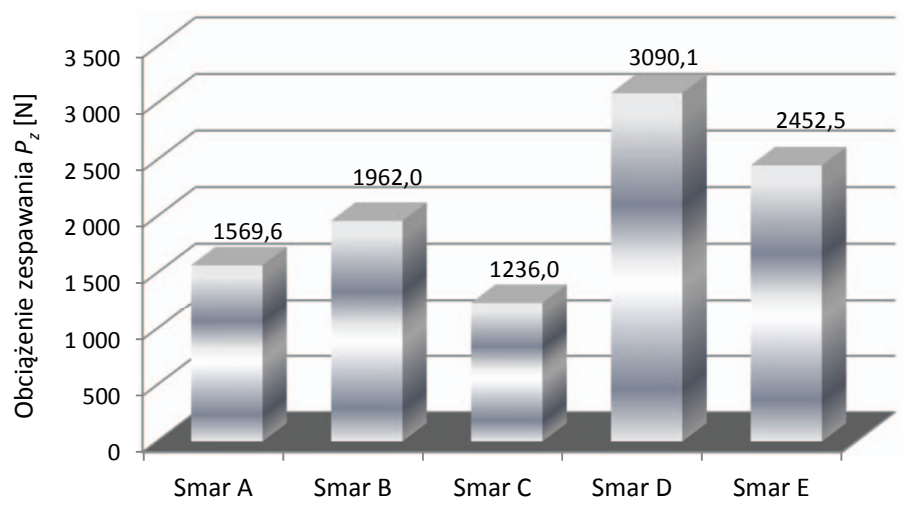

Rys. 1. Obciążenie zespawania węzła tarcia smarowanego kompozycjami wytworzonymi na oleju lnianym z różnymi zagęszczaczami 
Właściwości przeciwzatarciowe przy skokowo narastającym obciążeniu węzła tarcia dla smarów plastycznych poddanych badaniom zależą od rodzaju fazy zdyspergowanej, która wpływa w znaczący sposób na trwałość filmu smarowego (rysunek 1). Najkorzystniejszymi właściwościami przeciwzatarciowymi charakteryzuje się kompozycja, w której jako zagęszczacz zastosowano krzemionkę amorficzną Aerosil ${ }^{\circledR}$ (smar D) oraz kompozycja, w której fazą rozpraszaną był glinokrzemian warstwowy - montmorylonit (smar E). Natomiast najsłabszymi właściwościami przeciwzatarciowymi charakteryzuje się kompozycja, w której jako fazę zdyspergowaną zastosowano stearynian wapnia (smar C). Kompozycje smarowe wytworzone na oleju lnianym i zagęszczone stearynianem litu (smar A) oraz stearynianem glinu (smar B) charakteryzują się pośrednimi wartościami oznaczanego parametru. Wartość obciążenia zespawania $P_{z}$ dla kompozycji D (zagęszczonej krzemionką amorficzną) jest o $150 \%$ większa od wartości tego parametru dla kompozycji C, w której jako fazę zdyspergowaną zastosowano stearynian wapnia. Z przeprowadzonej analizy wynika więc, że najskuteczniejszą ochronę przeciwzatarciową przy skokowo narastającym obciążeniu węzła tarcia reprezentuje kompozycja smarowa, w której jako zagęszczacz zastosowano krzemionkę amorficzną Aerosil ${ }^{\circledR}$, a najmniej skuteczne działanie przeciwzatarciowe stwierdzono w przypadku kompozycji, w której fazą zdyspergowaną był stearynian wapnia.

Miarą właściwości przeciwzatarciowych badanych kompozycji smarowych w warunkach zacierania jest graniczny nacisk zatarcia $p_{o z}$. Uzyskane wyniki badania tego parametru przedstawiono na rysunku 2.

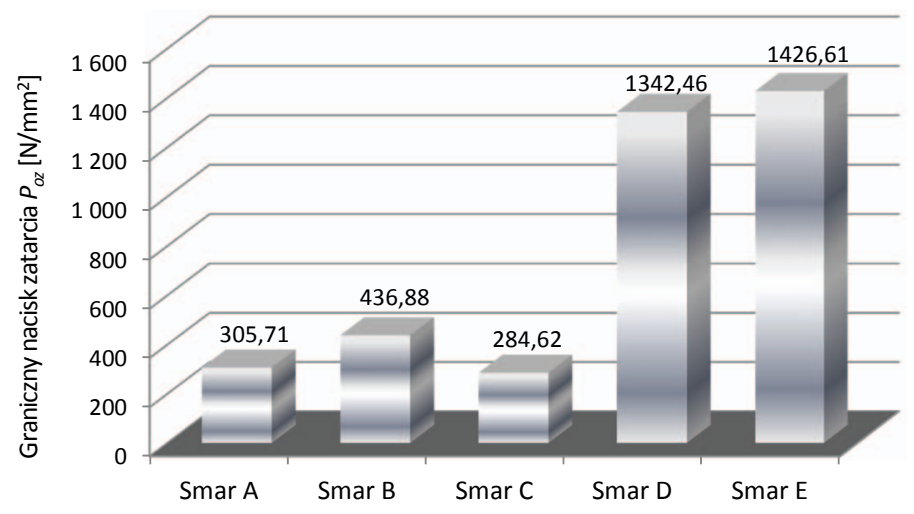

Rys. 2. Graniczny nacisk zatarcia węzła tarcia smarowanego kompozycjami wytworzonymi na oleju lnianym z różnymi zagęszczaczami

Wyznaczone wartości granicznego nacisku zatarcia wykazały zróżnicowany poziom właściwości przeciwzatarciowych badanych kompozycji smarowych. W zależności od zastosowanego zagęszczacza dla badanych smarów plastycznych wartość parametru określającego poziom właściwości przeciwzatarciowych ulegała istotnym zmianom. Największą wartością parametru $p_{o z}$ charakteryzuje się kompozycja E, gdzie jako fazę rozpraszaną zastosowano montmorylonit - przedstawiciela glinokrzemianów warstwowych. Kompozycja D, w której fazą zdyspergowaną była krzemionka amorficzna Aerosil ${ }^{\circledR}$ charakteryzuje się dużą wartością parametru $p_{o z}$, podobnie jak kompozycja E. Najmniejszą wartość tego parametru zaobserwowano dla smaru $\mathrm{C}$, w którym fazą zdyspergowaną był stearynian wapnia. Kompozycje A, B i C charakteryzują się porównywalnymi wartościami granicznego nacisku zatarcia $p_{o z}$, który odzwierciedla poziom ich właściwości przeciwzatarciowych. Wartość granicznego nacisku zatarcia $p_{o z}$ dla kompozycji E (zagęszzczonej montmorylonitem) jest ponad czterokrotnie, a dla kompozycji D (zagęszczonej krzemionką amorficzną) prawie czterokrotnie większa od wartości tego parametru dla kompozycji C, w której jako fazę zdyspergowaną zastosowano stearynian wapnia.

Kompozycje smarowe wytworzone na oleju lnianym i zagęszczone stearynianem litu, stearynianem glinu i stearynianem wapnia nie wykazywały tak korzystnych właściwości przeciwzatarciowych jak kompozycje, w których jako fazę zdyspergowaną zastosowano modyfikowaną krzemionkę amorficzną Aerosil $^{\circledR}$ oraz montmorylonit (rysunek 2). Wyznaczone wartości granicznego nacisku zatarcia wykazały, że zastosowanie krzemionki amorficznej oraz glinokrzemianu warstwowego jako zagęszczaczy smarów plastycznych najkorzystniej wpływa na zwiększenie odporności warstwy wierzchniej na zacieranie, niż stosowanie zagęszczaczy mydlanych w badanych kompozycjach smarowych zastosowanych w eksperymencie. Parametr $p_{o z}$ dostarcza informacji o ciśnieniu panującym w strefie tarcia w momencie zatarcia. Na podstawie otrzymanych wyników można stwierdzić, że zastosowanie montmorylonitu oraz krzemionki amorficznej do komponowania smarów plastycznych wpływa na tworzenie wysoko odpornych na zacieranie warstw wierzchnich. Natomiast zastosowanie zagęszczaczy mydlanych do wytwarzania kompozycji smarowych nie wpływa na tworzenie odpornych na zacieranie warstw wierzchnich. Większy parametr $p_{o z}$ w porównaniu z kompozycjami zagęszczonymi stearynianem litu bądź wapnia dla kompozycji smarowej, w której jako fazę zdyspergowaną zastosowano stearynian glinu wskazuje, że charakter tworzonego filmu sprzyja zmniejszeniu zużycia.

Z przeprowadzonej analizy wynika więc, że najskuteczniejszą ochronę przeciwzatarciową węzła tarcia reprezentuje kompozycja smarowa, w której jako zagęszczacz zastosowano montmorylonit - przedstawiciela glinokrzemianów warstwowych, a najmniej skuteczne działanie przeciwzatarciowe stwierdzono w przypadku kompozycji, w której fazą zdyspergowaną był stearynian wapnia.

Dla wszystkich sporządzonych kompozycji smarowych wyznaczono właściwości przeciwzatarciowe w warunkach liniowo 
wzrastającego obciążenia, charakteryzowane obciążeniem zacierającym $P_{t}$. Uzyskane wyniki przedstawiono na rysunku 3.

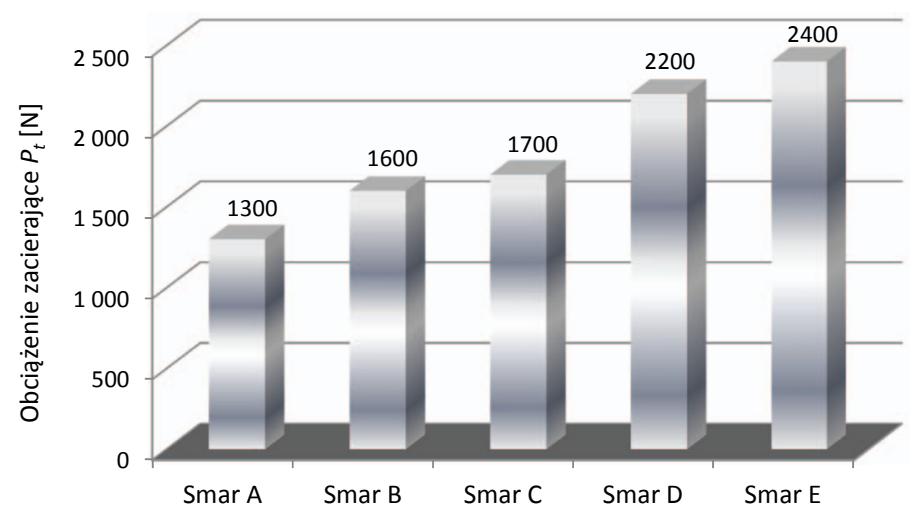

Rys. 3. Obciążenie zacierające węzeł tarcia smarowany kompozycjami wytworzonymi na oleju lnianym z różnymi zagęszczaczami

Obciążenie zacierające określa poziom właściwości przeciwzatarciowych badanych smarów w warunkach liniowo wzrastającego obciążenia. Właściwości charakteryzowane przez parametr $P_{t}$ określają zdolność filmu smarnego do przenoszenia obciążeń. W zależności od rodzaju fazy zdyspergowanej zastosowanej do wytworzenia smarów plastycznych, wartość obciążenia zacierającego ulegała zmianom. Najkorzystniejszymi właściwościami przeciwzatarciowymi w warunkach liniowo wzrastającego obciążenia charakteryzuje się kompozycja smarowa wytworzona na bazie oleju lnianego i zagęszczona montmorylonitem (kompozycja E). Kompozycja D, w której fazą zdyspergowaną była krzemionka amorficzna Aerosil ${ }^{\circledR}$ charakteryzuje się porównywalną wartością parametru $P_{t}$ do kompozycji E. Najmniejszą wartość tego parametru zaobserwowano dla smaru A, w którym fazą zdyspergowaną był stearynian litu. Kompozycje B i C charakteryzują się porównywalnymi wartościami obciążenia zacierającego $P_{t}$, które określa poziom ich właściwości przeciwzatarciowych w warunkach liniowo wzrastającego obciążenia węzła tarcia. Wartość obciążenia zacierającego dla kompozycji E jest o 84,6\%, a dla kompozycji D o 69,2\% większa od wartości tego parametru dla kompozycji A, w której jako fazę zdyspergowaną zastosowano stearynian litu. Zatem rodzaj zastosowanej do komponowania smarów plastycznych fazy rozpraszanej ma wpływ na zmianę właściwości przeciwzatarciowych badanych kompozycji smarowych. Kompozycje smarowe wytworzone na oleju lnianym przy udziale zagęszczaczy mydlanych nie wykazywały tak korzystnych właściwości przeciwzatarciowych jak kompozycje zagęszczone montmorylonitem i modyfikowaną krzemionką amorficzną Aerosil ${ }^{\circledR}$ (rysunek 3). Największą trwałość filmu smarowego zapewnia zastosowanie krzemionki amorficznej i montmorylonitu jako fazy zdyspergowanej wytworzonych kompozycji smarowych, które umożliwiają uzyskanie smarów o największej wartości parametru $P_{t}$. Można zatem zakładać, że skuteczność przeciwdziałania zacieraniu będzie zależeć od struktury warstwy granicznej tworzonej przez zastosowane zagęszczacze. Poszczególne cząsteczki fazy zdyspergowanej w filmie smarowym są ściślej upakowane, co wpływa na zwiększenie ich wzajemnych oddziaływań, a więc zwiększa się odporność filmu smarowego na przenoszenie większych obciążeń.

Wyznaczono także graniczne obciążenie zatarcia węzła tarcia smarowanego badanymi kompozycjami smarowymi. Uzyskane wyniki przedstawiono na rysunku 4.

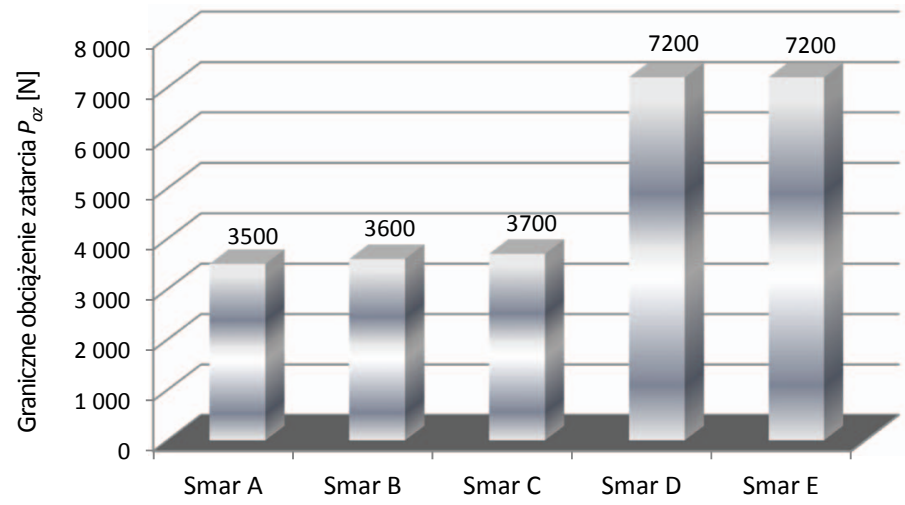

Rys. 4. Graniczne obciążenie zatarcia węzła tarcia smarowanego kompozycjami wytworzonymi na oleju lnianym z różnymi zagęszczaczami

Graniczne obciążenie zatarcia $P_{o z}$ pozwala określić poziom właściwości przeciwzatarciowych badanych kompozycji smarowych. Najkorzystniejszymi właściwościami przeciwzatarciowymi charakteryzują się smary, w których jako fazę zdyspergowaną zastosowano modyfikowaną krzemionkę amorficzną oraz montmorylonit - przedstawiciela glinokrzemianów warstwowych (kompozycja D i E). Najmniejszą wartość tego parametru zaobserwowano dla smaru A, w którym fazą zdyspergowaną był stearynian litu. Kompozycje A, B i C charakteryzują się porównywalnymi wartościami granicznego obciążenia zatarcia $P_{o z}$, które określa poziom ich właściwości przeciwzatarciowych. Wartość granicznego obciążenia zatarcia dla kompozycji D i E jest o 105,7\% większa od wartości tego parametru dla kompozycji A, w której jako fazę zdyspergowaną zastosowano stearynian litu. Zatem rodzaj zastosowanej do komponowania smarów plastycznych fazy zdyspergowanej ma duży wpływ na zmianę właściwości przeciwzatarciowych badanych kompozycji smarowych. Kompozycje wytworzone na oleju lnianym i zagęszczone stearynianem litu, wapnia bądź glinu nie wykazywały tak korzystnych właściwości przeciwzatarciowych jak kompozycje, w których jako fazę zdyspergowaną zastosowano montmorylonit i modyfikowaną krzemionkę amorficzną (rysunek 4). Najskuteczniejsze działanie środka smarowego po przerwaniu filmu smarowego 
zapewnia zastosowanie krzemionki amorficznej i montmorylonitu jako zagęszczaczy kompozycji smarowych, ponieważ zagęszczacze te umożliwiają uzyskanie smarów charakteryzujących się największą wartością parametru $P_{o z}$. Dla kompozycji, w których jako fazę zdyspergowaną zastosowano zagęszczacze mydlane (smary A, B i C) wartości parametru $P_{o z}$ mieszczą się w granicach $3500 \div 3700 \mathrm{~N}$, co może świadczyć o tym, że różnice w składzie badanych kompozycji smarowych odgrywają istotną rolę jedynie w warunkach umiarkowanych wymuszeń. W przypadku kompozycji wytworzonych z udziałem zagęszczaczy zawierających krzem (krzemionka amorficzna oraz montmorylonit), wartość granicznego obciążenia zatarcia osiąga wartość 7200 N, co może świadczyć, że badane kompozycje smarowe skutecznie chronią węzeł tarcia przed zatarciem w warunkach dużych wymuszeń. W trakcie procesu zacierania zwiększające ciśnienie w strefie tarcia powoduje, że na współpracujących powierzchniach nie ma już filmu smarnego. Działanie ochronne przed unieruchomieniem węzła tarcia są w stanie zapewnić zastosowane kompozycje smarowe mogące wejść w reakcję z materiałem pary ciernej. Efektem tego jest ograniczenie możliwości powstawania szczepów adhezyjnych.

Właściwości przeciwzużyciowe badanych smarów plastycznych zweryfikowano poprzez wyznaczenie granicznego obciążenia zużycia $G_{o z / 40}$ węzła tarcia smarowanego ocenianymi kompozycjami. Uzyskane wyniki przedstawiono na rysunku 5.

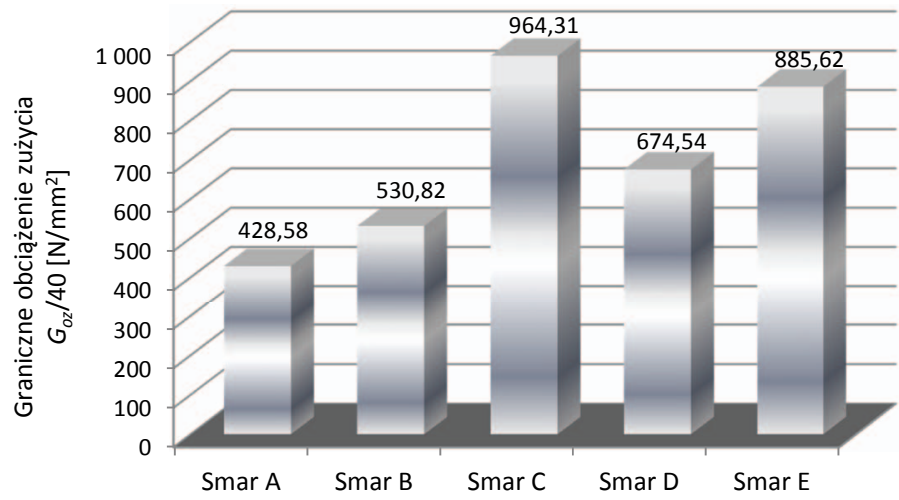

Rys. 5. Graniczne obciążenie zużycia węzła tarcia smarowanego kompozycjami wytworzonymi na oleju lnianym z różnymi zagęszczaczami

Badania właściwości smarnych wytworzonych kompozycji smarowych wykazały, że zastosowane zagęszczacze zmieniły zdolność smarów do przeciwzużyciowej ochrony węzła tarcia. O trwałości warstwy granicznej świadczy wartość granicznego obciążenia zużycia $G_{o z / 40}$. Im większy wskaźnik, tym większa trwałość warstwy granicznej i zmniejszenie zużycia. Największą wartością granicznego obciążenia zużycia charakteryzuje się kompozycja smarowa, w której jako fazę zdyspergowaną zastosowano stearynian wapnia.
Kompozycja E, w której fazą zdyspergowaną był glinokrzemian warstwowy - montmorylonit, cechuje się porównywalną wartością parametru $G_{o z / 40}$ do kompozycji C. Natomiast najmniejszą wartość tego parametru zaobserwowano dla smaru A, w którym fazą rozpraszaną był stearynian litu. Wartość granicznego obciążenia zużycia dla kompozycji B jest o 23,9\%, a dla kompozycji D o 57,4\% większa od wartości tego parametru dla kompozycji A, w której jako fazę zdyspergowaną zastosowano stearynian litu. Natomiast kompozycja smarowa zagęszczona montmorylonitem charakteryzuje się większą o 106,6\% ochroną przeciwzużyciową niż smar plastyczny wytworzony z udziałem stearynianu litu. Kompozycja, w której jako fazę zdyspergowaną zastosowano stearynian wapnia (smar C) wykazuje bardzo dobre właściwości przeciwzużyciowe, większe o $125 \%$ od kompozycji zagęszczonej mydłem litowym. Stwierdzono, że zastosowanie zarówno zagęszczaczy mydlanych, jak i nieorganicznych jako fazy zdyspergowanej smarów plastycznych ma korzystny wpływ na właściwości przeciwzużyciowe badanych kompozycji smarowych. Największą trwałość przeciwzużyciową zapewnia zastosowanie stearynianu wapnia jako fazy zdyspergowanej wytworzonych kompozycji smarowych, który umożliwia uzyskanie smaru charakteryzującego się największą wartością parametru $G_{o z / 40}$. Zatem rodzaj zastosowanej do komponowania smarów plastycznych fazy zdyspergowanej ma wpływ na wartość granicznego obciążenia zużycia badanych kompozycji smarowych. Porównanie właściwości przeciwzużyciowych kompozycji smarowych, w których jako fazę zdyspergowaną zastosowano zagęszczacze mydlane oraz krzemionkę amorficzną i montmorylonit, sporządzonych na roślinnych olejach bazowych z kompozycjami wytworzonymi na olejach syntetycznych czy mineralnych, przy tej samej fazie zdyspergowanej wskazuje, że zastosowanie olejów roślinnych jako bazy olejowej smarów plastycznych warunkuje skuteczną ochronę przeciwzużyciową, czego nie można powiedzieć o środkach smarowych wytworzonych na olejach syntetycznych czy mineralnych [20, 21, 24].

Kryteria jakości środków smarowych szczególnie dla przemysłu spożywczego są ustalane indywidualnie przez producentów maszyn. W wyniku przeprowadzonej analizy rynku można stwierdzić, że kompozycje smarowe, dla których $G_{o z / 40}>600 \mathrm{~N} / \mathrm{mm}^{2}$ charakteryzują się bardzo dobrymi właściwościami przeciwzużyciowymi, te których graniczne obciążenie zużycia mieści się w przedziale 400 $600 \mathrm{~N} / \mathrm{mm}^{2}$ zapewniają skuteczną ochronę przeciwzużyciową, natomiast jeśli $G_{o z / 40}<400 \mathrm{~N} / \mathrm{mm}^{2}$, to mówimy wtedy o niedostatecznych właściwościach przeciwzużyciowych. Uzyskany poziom właściwości przeciwzużyciowych czyni wszystkie badane kompozycje smarowe skutecznymi produktami smarnymi w warunkach stałego obciążenia węzła tarcia. 


\section{Podsumowanie}

Przeprowadzone badania wykazały zróżnicowany wpływ zastosowanej fazy zdyspergowanej na właściwości przeciwzatarciowe i przeciwzużyciowe kompozycji smarowych poddanych testom. Kompozycje, w których jako fazę zdyspergowaną zastosowano amorficzną krzemionkę Aerosil ${ }^{\circledR}$ oraz montmorylonit charakteryzują się bardzo dobrymi właściwościami przeciwzatarciowymi w warunkach skokowo narastającego obciążenia węzła tarcia. Inne kompozycje charakteryzowały się mniejszymi wartościami tego parametru.

Największy poziom właściwości przeciwzatarciowych w warunkach zacierania zaobserwowano w smarach sporządzonych na bazie oleju lnianego i zagęszczonych krzemionką amorficzną Aerosil ${ }^{\circledR}$ oraz montmorylonitem, natomiast kompozycje, w których fazą zdyspergowaną był stearynian (litu, glinu i wapnia), nie zapewniały satysfakcjonującej ochrony przeciwzatarciowej. W warunkach liniowo wzrastającego obciążenia węzła tarcia najskuteczniejszą ochronę przeciwzatarciową reprezentują kompozycje smarowe, w których jako fazę rozproszoną zastosowano krzemionkę amorficzną oraz montmorylonit. Pozostałe kompozycje, w których fazą zdyspergowaną były zagęszczacze mydlane, charakteryzują się podobnym poziomem tego parametru, ale mniejszym od kompozycji, w których zastosowano zagęszczacze zawierające w swym składzie krzem. Zastosowanie glinokrzemianu warstwowego (montmorylonitu) lub krzemionki amorficznej jako zagęszczaczy kompozycji smarowych powoduje utworzenie ochronnego filmu na powierzchni, co w konsekwencji prowadzi do zwiększenia odporności węzła na zacieranie. W wyniku poprawy właściwości warstwy granicznej, początek fazy zacierania następuje przy większych obciążeniach węzła tarcia.
Zastosowanie stearynianu wapnia i montmorylonitu jako fazy zdyspergowanej badanych smarów plastycznych spowodowało zwiększenie wartości parametru $G_{o z}$ w porównaniu z kompozycjami zagęszczonymi stearynianem litu, stearynianem glinu i krzemionką amorficzną, co świadczy o dużej odporności badanych kompozycji smarowych zagęszczonych mydłem wapniowym i montmorylonitem na przerwanie warstwy granicznej.

Uzyskane wyniki pozwalają na stwierdzenie, że właściwości smarne testowanych kompozycji uległy znacznej zmianie w zależności od zastosowanej fazy zdyspergowanej. Niektóre z badanych kompozycji smarnych wyjątkowo skutecznie chroniły węzeł tarcia przed zużyciem (wytworzone na bazie oleju lnianego i zagęszczone stearynianem wapnia i montmorylonitem), podczas gdy inne były niezwykle odporne na proces zacierania (kompozycje, w których fazą zdyspergowaną była krzemionka amorficzna Aerosil ${ }^{\circledR}$ oraz montmorylonit). Wielkość zmian zależała zatem od właściwości fizykochemicznych oraz strukturalnych zastosowanych zagęszczaczy, które w decydujący sposób wpływają na właściwości smarne otrzymanych smarów plastycznych. Wynika z tego, że kompozycje smarowe wytworzone na bazie oleju lnianego i zagęszczone krzemionką amorficzną i montmorylonitem odznaczają się wyjątkowo korzystnymi właściwościami smarnymi oraz mogą być stosowane do ochrony węzłów tarcia w wielu gałęziach przemysłu.

Wskazane jest prowadzenie dalszych badań nad wyjaśnieniem mechanizmu tak skutecznego działania przeciwzatarciowego krzemionki amorficznej i montmorylonitu oraz przeciwzużyciowego działania stearynianu wapnia w badanych smarach plastycznych, gdzie jako fazę dyspergującą zastosowano olej lniany.

Prosimy cytować jako: Nafta-Gaz 2018, nr 6, s. 471-478, DOI: 10.18668/NG.2018.06.08

Artykuł nadesłano do Redakcji 22.02.2018 r. Zatwierdzono do druku 8.05.2018 r.

\section{Literatura}

[1] Bajer J.: Wplyw wymuszeń mechanicznych $i$ wody na charakterystyki tribologiczne smaru plastycznego. Tribologia 2007, $\mathrm{nr} 6$, s. 63-73.

[2] Bajer J., Janecki J.: Syntetyczne smary plastyczne do różnych zastosowań. Problemy Eksploatacji 2004, nr 2, s. 199-206.

[3] Bajer J., Janecki J.: Syntetyczny ekologiczny smar łożyskowy. Problemy Eksploatacji 2000, nr 4, s. 227-236.

[4] Bartz W.J.: Ecotribology: environmentally acceptable tribological practices. Tribology International 2006, nr 39, s. 728-733.

[5] Bartz W.J.: Lubricants and the environment. Tribology International 1998, nr 31, s. 35-47.

[6] Beran E.: Experience with evaluating biodegrability of lubricating base oils. Tribology International 2008, nr 12, s. 1212-1218.

[7] Bloch H.P.: Practical lubrication for industrial facilities. Fairmont Press, London 2000.

[8] Cubberly W.H., Bakerjian R.: Tool and manufacturing engineers handbook. Society of Manufacturing Engineers, New York 1992.

[9] Czarny R.: Smary plastyczne. WNT, Warszawa 2004.
[10] Dąbrowski J.R.: Zagadnienia ekologiczne użytkowania substancji smarowych. Wydawnictwo Politechniki Częstochowskiej, Częstochowa 1997.

[11] Drabik J., Iłowska J., Gniady J., Kozupa M., Szmatoła M., Semeniuk I.: Wpływ bazy olejowej $i$ składu zageszczacza na właściwości użytkowe smarów plastycznych. Przemysł Chemiczny 2012, nr 10, s. 1922-1926.

[12] Drabik J., Pawelec E., Janecki J.: Charakterystyka biodegradowalnych baz olejowych ekologicznych smarów plastycznych. Tribologia 2003, nr 5, s. 23-37.

[13] Drabik J., Pawelec E., Janecki J.: Modelowanie właściwości oraz technologii ekologicznych smarów plastycznych. Problemy Eksploatacji 2001, nr 2, s. 67-79.

[14] Erhan S.Z., Asadauskas S.: Lubricant basestocks from vegetable oils. Industrial Crops and Products 2000, vol. 11, nr 2-3, s. 277-282.

[15] Fiszer S., Szałajko U.: Oleje roślinne jako substytuty środków smarowych pochodzenia naftowego. Nafta-Gaz 2000, nr 3, s. 181-188. 
[16] Fox N.J., Stachowiak G.W.: Boundary lubrication properties of oxidized sunflower oil. Journal of the Society of Tribologist and Lubrication Engineers 2003, nr 2, s. 15-20.

[17] Grądkowski M., Rogoś E., Urbański A.: Właściwości smarne wybranych olejów roślinnych. Tribologia 2001, nr 3, s. 381-393.

[18] Iłowska J., Bereska B., Drabik J., Kozdrach R.: Odporność oksydacyjna i wtaściwości smarne stabilizowanych roślinnych baz olejowych. Tribologia 2011, nr 5, s. 69-80.

[19] Ishchuk Y.L.: Lubricating grease manufacturing technology. New Age International, New York 2008.

[20] Janecki J., Bajer J., Drabik J., Pawelec E.: Wpływ syntetycznej fazy dyspersyjnej na charakterystyki tribologiczne plastycznego środka smarowego. POLTRIB '99, Szczyrk 1999, s. 64-70.

[21] Janecki J., Drabik J., Pawelec E., Bajer J.: Ocena możliwość stosowania olejów naturalnych i syntetycznych jako ciecze bazowe smarów plastycznych. Problemy Eksploatacji 1999, nr 4, s. 49-54.

[22] Janecki J., Drabik J., Pawelec E., Bajer J.: Sprawozdanie z realizacji działalności statutowej „Badanie wpływu biodegradowalnych baz olejowych na właściwości smaru plastycznego”. Instytut Technologii Eksploatacji - Państwowy Instytut Badawczy, Radom 1998.

[23] Janecki J., Drabik J., Pawelec E., Bajer J.: Uruchomienie produkcji nietoksycznych środków smarowych przeznaczonych do maszyn i urządzeń przemystu spożywczego. Program celowy, Instytut Technologii Eksploatacji - Państwowy Instytut Badawczy, Radom 1997-2000.

[24] Janecki J., Pawelec E., Drabik J.: Wptyw rodzaju baz olejowych na właściwości tribologiczne smarów plastycznych. XXIII Jesienna Szkoła Tribologiczna, Zielona Góra-Lubiatów 1999, Tribologia 1999, nr 6, s. 809-815.

[25] Kato N., Komiya H., Kimura A., Kimura H.: Lubrication life of biodegradable greases with rapeseed oil base. Journal of the Society of Tribologist and Lubrication Engineers 1998, nr 8, s. 19-25.

[26] Kozdrach R.: The tribological properties of lubricating greases based on renewable oils. Tribologia 2016, $\mathrm{nr}$ 2, s. 61-72.

[27] Kozdrach R.: Wplyw nanododatków ceramicznych na charakterystyki tribologiczne biodegradowalnych smarów plastycznych. Tribologia 2012, nr 4, s. 75-88.

[28] Kozdrach R.: Wplyw rodzaju fazy dyspergującej na zmianę właściwości tribologicznych smarów plastycznych. Tribologia 2012, nr 6, s. 85-97.

[29] Kozdrach R.: Wpływ synergizmu dodatków zawierających krzem na zmiany charakterystyk trybologicznych smaru plastycznego. Nafta-Gaz 2015, nr 2, s. 110-118.

[30] Kozdrach R.: Wplyw wymuszeń mechanicznych na zmianę właściwości smarnych biodegradowalnego smaru plastycznego wytworzonego na bazie roślinnej. Nafta-Gaz 2012, nr 11, s. 868-876.

[31] Kozdrach R.: Zastosowanie montmorylonitu jako dodatku modyfikujacego wtaściwości tribologiczne smaru plastycznego wytworzonego na bazie roślinnej. Nafta-Gaz 2015, nr 12, s. 1029-1036, DOI: 10.18668/NG2015.12.12.

[32] Kozdrach R., Bajer J., Drabik J.: Wpływ rodzaju zagęszczacza na charakterystyki tribologiczne smarów plastycznych. Tribologia 2011, nr 1, s. 73-83.

[33] Kozdrach R., Drabik J., Pawelec E., Molenda J.: Wpływ dodatku modyfikującego AR na właściwości tribologiczne ekologicznych smarów plastycznych. Tribologia 2010, nr 1, s. 27-39.

[34] Kozdrach R., Drabik J., Pawelec E., Molenda J.: Wptyw dodatku modyfikujacego na bazie polimerowo-krzemionkowej oraz wymuszeń mechanicznych na właściwości fizykochemiczne ekologicznych smarów plastycznych. Tribologia 2010, nr 2, s. 35-46.

[35] Kozdrach R., Molenda J.: Testowanie właściwości eksploatacyjnych ekologicznych smarów plastycznych modyfikowanych dodatkiem polimerowo-krzemionkowym. Tribologia 2012, nr 6, s. 99-111.

[36] Łubiński J., Śliwiński P.: Multi parameter sliding test result evaluation for the selection of material pair for wear resistant components of a hydraulic motor dedicated for use with environ- mentally friendly working fluids. Solid State Phenomena 2015, nr 225, s. 115-122.

[37] Molenda J., Grądkowski M., Urbański A.: Urządzenie do oceny konsystencji plastycznych środków smarowych. Problemy Eksploatacji 2001, nr 2, s. 155-165.

[38] Molenda J., Samborski T., Wojutyński J.: Penetrometry do badania właściwości reologicznych smarów plastycznych. Problemy Eksploatacji 2003, nr 3, s. 111-125.

[39] Mortier R.M., Fox M.F., Orszulik S.T.: Chemistry and technology of lubricants. Springer, Munchen 2009.

[40] Mucha J., Stańkowski L.: Smary plastyczne - cz. 2. Paliwa, Oleje i Smary w Eksploatacji 1993, nr 5, s. 22-23.

[41] Pawelec E., Bajer J., Drabik J., Janecki J.: Biały smar plastyczny $P B$ do tożysk tocznych i ślizgowych. VIII Krajowy Kongres Eksploatacji Urządzeń Technicznych, Krynica 1997.

[42] Pawelec E., Drabik J., Bajer J., Janecki J.: Nietoksyczny środek smarowy - SMAR PB. IV Międzynarodowe Sympozjum Forum Chemiczne 98, Warszawa 1998.

[43] Pawelec E., Drabik J.: Możliwość zastosowania nietoksycznych olejów do smarowania łożysk tocznych i ślizgowych. Tribologia 2006, nr 5, s. 57-66.

[44] Pawelec E., Drabik J.: Wpływ komponentów na charakterystyki tribologiczne ekologicznego smaru plastycznego. Tribologia 2007, nr 5, s. 109-117.

[45] Podniadło A.: Paliwa, oleje i smary w ekologicznej eksploatacji. WNT, Warszawa 2002

[46] Program Wieloletni PW-004 pn.: Doskonalenie systemów rozwoju innowacyjności w produkcji i eksploatacji w latach 2004-2008. Instytut Technologii Eksploatacji - Państwowy Instytut Badawczy, Radom 2009.

[47] Rogoś E.: Badania olejów roślinnych jako składników bazowych olejów przemysłowych. Przemysł Chemiczny 2016, vol. 95, nr 1, s. $103-106$.

[48] Smary plastyczne: Wiadomości ogólne (cz. I). Paliwa, Oleje i Smary w Eksploatacji 1996, nr 30, s. 10-14.

[49] Stachowiak G., Batchelor A.W.: Engineering tribology. Elsevier, Oxford 2007.

[50] Szczerek M., Tuszyński W.: Badania tribologiczne. Zacieranie. Instytut Technologii Eksploatacji - Państwowy Instytut Badawczy, Radom 2000.

[51] Trzaska E.: Kompleksowe smary litowe. Nafta-Gaz 2003, nr 11, s. $528-535$.

[52] Tuszyński W., Szczerek M., Michalczewski R., Osuch-Słomka E., Rogoś E., Urbański A.: The potential of the application of biodegradable and nontoxic base oils for the formulation of gear oils - model and component scuffing tests. Lubrication Science 2014, vol. 26, nr 5, s. 327-346.

[53] Wiggins G.: Biodegradable vegetable oil grease. Journal of Cleaner Production 1997, nr 1-2, s. 180-182.

\section{Akty prawne i normatywne}

[54] PN-76/C-04147 Przetwory naftowe. Badanie wlasności smarnych olejów i smarów, 1976.

[55] WTWT-94/MPS-025 Wojskowe Tymczasowe Wymagania Techniczne. Badanie właściwości przeciwzużyciowych materiatów pędnych i smarowych, 1994.

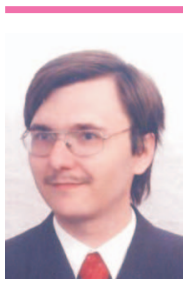

Mgr inż. Rafał KOZDRACH

Instytut Technologii Eksploatacji - Państwowy

Instytut Badawczy

ul. Pułaskiego 6/10

26-600 Radom

E-mail: rafal.kozdrach@itee.radom.pl 